\title{
MISTR JAN HUS A PRAŽSKÁ UNIVERZITA: NĚKOLIK ZAMYŠLENÍ NAD MOŽNOSTMI POZNÁNÍ JEJICH VZÁJEMNÉHO VZTAHU A HUSOVY PEDAGOGICKÉ ČINNOSTI*
}

\author{
BLANKA ZILYNSKÁ
}

\section{MASTER JAN HUS AND THE PRAGUE UNIVERSITY. SOME CONSIDERATIONS UPON POSSIBILITIES OF LEARNING ABOUT THEIR MUTUAL RELATIONS AND HUS'S TEACHING ACTIVITIES}

\begin{abstract}
Hus's professional and personal life was closely linked to the Prague University. In addition to summarising various aspects of their mutual relation, this contribution focuses on Hus's students, their numbers, and possibility of identifying them in more detail. The author also discusses Hus's functions within the university administration and examines their importance and impact. The study is based on the official books of the dean's office and on the study of the document fonds of Charles University Archive, with the purpose of showing the role of the Prague University in Hus's case.
\end{abstract}

Keywords: Jan Hus - university - masters - students $-15^{\text {th }}$ century

DOI: $10.14712 / 23365730.2018 .32$

Mistr Jan Hus je neoddělitelně spojen s pražskou univerzitou a o vztahu mistra a jeho alma mater byla napsána slušná řádka pojednání, počínaje Václavem Novotným ${ }^{1}$ a především F. M. Bartošem, ${ }^{2}$ přes Anežku Vidmanovou ${ }^{3}$ až po Michala Svatoše, ${ }^{4}$ Karla Malého,

* Téma bylo předneseno v záŕí 2015 na konferenci pořádané Rektorátem Univerzity Karlovy pod názvem Jan Hus a pražská univerzita - sekce UK. Ke konferenci viz Jan B. LÁšEK, Editorial, Theologická revue 87/1, 2016, s. 5-8. Písemná verze zpracována v rámci projektu PROGRES Q23 (Dějiny univerzitní vědy a vzdělanosti).

1 Václav NovotnÝ, Hus rektorem Pražské university, Naše doba 17, 1910, s. 648-657, 727-734; TÝž, M. J. Hus. Život a učení, I/1-2, Život a dílo, Praha 1919-1921.

2 František Michálek BARToš, M. J. Hus jako rektor Karlovy university, Praha 1936; TÝž, Dvě rektorské reči Husovy, Jihočeský sborník historický 10, 1937, s. 1-15; TÝž, Hus jako student a profesor Karlovy university, Acta Universitatis Carolinae - Philosophica et Historica 2, Praha 1958, s. 9-26.

3 Kamil Krofta, Hus a pražská universita, Praha 1910; Václav FlajšHans, Husovi učitelé, Věstník České akademie 18, 1909, s. 245-254; Evžen SteIn (ed.), M. Jan Hus jako universitni rektor a profesor. Výbor z jeho projevů, Praha 1948; Anežka Schmidtová/Vidmanová/ (ed.), Iohannes Hus, magister Universitatis Carolinae: Positiones, recommendationes, sermones / M. Jan Hus: universitni promluvy, Praha 1958, s předmluvou: František KavKA, Mistr Jan Hus a Universita Karlova, s. 5-18 (lat. a čes.).

4 Michal Svatoš, Das Kuttenberger Dekret und das Wirken von Magister Jan Hus an der Prager Universität, in: Blanka Mouralová (ed.), Die Prager Universität Karls IV. Von der europäischen Gründung bis zur nationalen Spaltung, Potsdam 2010, s. 45-70. 
Petra Elbela a Martina Nodla. ${ }^{5}$ Protože se jedná o vztah mnohovrstevný, vždy se najde nový problém nebo aspekt, nad nímž je možné se pozastavit. Pokusme se proto o bilanci bádání a položme si otázku, jaké jsou k dispozici prameny a co je možné ještě udělat pro poznání Husova působení na Karlově vysokém učení.

Univerzitní úřední písemnosti, především děkanská kniha artistické fakulty, přinášejí v rámci dobových pramenů nejspolehlivější svědectví k Husovu životu. ${ }^{6}$ Přes toto hrdé konstatování ani záznamy univerzitní (respektive fakultní) kanceláře neodpovídají na všechny otazníky kolem Husova studia a učitelského působení. Velkým přínosem je dále Husova kvodlibetní príručka ${ }^{7}$ a soubor jeho promočních proslovů. ${ }^{8}$ Ostatní písemnosti pak vyvolávají spíše další otazníky, at již máme na mysli subjektivní korespondenci, nebo polovičaté výpovědi náhodných př́ípisků v literárních kodexech.

Postup Husova studia je doložen dosti standardně, na rozdíl od údajů o způsobu zajištění jeho zázemí na studiích. ${ }^{9}$ Známá a často opakovaná fakta ale nebudu probírat detailně. Hus prošel běžné curriculum studijních povinností bakalářského i magisterského stupně na artistické fakultě ${ }^{10} \mathrm{a}$ dospěl až $\mathrm{k}$ teologickému bakalaureátu. ${ }^{11}$ Jeho průběh už lze sledovat méně soustavně, protože teologická fakulta postrádá děkanský manuálník nebo matriku a chronologie postupu Husa od výkladu biblických kapitol k Lombardovým Sentencím je možné odvozovat jen z prŕípisků a explicitů, kde se vyskytne jím dosažený titul. Nové vydání Enarratio Psalmorum přineslo vedle textu i upřesnění datace Husových výkladů. ${ }^{12}$ Zdůraznit také musíme, že Husova studia se omezila pouze na pražské studium generale, nebot' nepodnikl žádnou studijní cestu do zahraničí.

5 Karel MaLÝ, Mistr Jan Hus a Univerzita Karlova, in: Miloš Drda - Jindřich F. Holeček - Zdeněk Vybíral, Jan Hus na přelomu tisíciletí. Mezinárodní rozprava o českém reformátoru 15. stol., Papežská lateránská universita Ř́m 15.-18. prosince 1999 (Husitský Tábor - Supplementum 1), Tábor 2001, s. 395-404; Petr Elbel, Die Delegation der Prager Kirchenprovinz und die böhmischen Gegner des Jan Hus in Konstanz, in: Karl-Heinz Braun - Mathias Herweg - Hans W. Hubert - Joachim Schneider - Thomas Zotz (Hgg.), Das Konstanzer Konzil. Weltereignis des Mittelalters 1414-1418. Essays, Darmstadt 2013, s. 64-69; nejnověji Jana NechuTovÁ Jana Fuksová (edd.), Mistr Jan Hus v polemice a za katedrou. Překlady, komentáre a poznámky, Brno 2015; Martin Node, Jan Hus a pražská univerzita, in: Anna Paner - Marcin Hintz (edd.), Jan Hus. Życie i dzieło. W 600. rocznice śmierci, Gdańsk 2016, s. 73-83.

6 Monumenta historica Universitatis Carolo-Ferdinandeae Pragensis (dále MUP), I/1-2 = Liber decanorum facultatis philosophicae Universitatis Pragensis ab anno Christi 1367 usque ad annum 1585 (dále LD) I-II, Praha 1830-1832; faksimilové vydání: Liber decanorum etc. (dále LD-faksim.), Praha 1983.

7 Husova kvodlibetní příručka: František Michálek BARToš - Pavel Spunar, Soupis pramenů k literární činnosti M. Jana Husa a M. Jeronýma Pražského, Praha 1965 (dále LČ-Hus), s. 80-81, č. 21 (rukopis Knihovny Národního muzea, sign. V C 42); Jan SedLÁK, Husova disputace de quolibet (Studie a texty k náboženským dějinám českým I), Olomouc 1914, s. 1-21. Dále viz pozn. 34.

8 Viz edice E. Steina a A. Schmidtové (pozn. 3) a nová edice Nechutové a Fuksové cit. v pozn. 5.

9 Nejvíce spekulací v tomto směru asi naformuloval F. M. BARToš, Hus jako student a profesor; bez pramenných dokladů rozvíjí představy o jeho ochráncích, pobytu v Karolinu apod., stejně jako úvahy o usazení Husových žáků v Nazaretské koleji (viz dále). Reálněji vypadá jen předpoklad, že pomocníkem a patronem mu byl Křišs’an z Prachatic, který mu i dával opisovat texty (viz např. František ŠMAHEL, Jan Hus. Život a dilo, Praha 2013, s. 34).

10 Ke studiu na artistické fakultě LD I, s. 286-287, 309; LD-faksim., s. 153-154, 167 (folia ztraceného rukopisu $76 \mathrm{r}, 77 \mathrm{rv}, 84 \mathrm{r})$.

11 Studia sledují všechny životopisné monografie, např. V. NovotnÝ, M. J. Hus; F. ŠMAHEL, Jan Hus; Pavel SouKUP, Jan Hus. Prädiger - Reformator - Märtyrer (Kohlhammer-Urban-Taschenbücher, sv. 737), Stuttgart 2014; lehce upravená česká verze TÝž, Jan Hus. Život a smrt kazatele (Česká historie, sv. 31), Praha 2015.

12 Jana Nechutová et alt. (edd.), Magistri Iohannis Hus Enarratio Psalmorum (Ps. 109-118), Turnhout 2013 (Opera omnia MIH XVII; Corpus Christianorum, Continuatio Mediaevalis 253), zde Einleitung, s. X-XX. 
Po dosažení titulu mistra svobodných umění se Hus nechtěl vyhnout povinnému bienniu, naopak setrval na škole a zvolil (snad cíleně) dráhu vysokoškolského vzdělance, univerzitního mistra. ${ }^{13}$ Od roku 1398 se počíá mezi rádné mistry pražské univerzity - je magister regens..$^{14}$ Záhy se začal věnovat studentům nejen jako přednášející před auditoriem, nýbrž i osobně, jak lze soudit z faktu, že již v roce 1399 jej dva posluchači vybírají za svého promotora. ${ }^{15}$ Dokonce je možné, že svého úplně prvního studenta - Jana Černého z Řečice - promoval Hus o rok dříve, v postě $1398 .{ }^{16}$ Snad právě vůči mladším studentům pocítil ponejprv odpovědnost za to, co jim předává ze svého poznání: můžeme v tom vidět předstupeň jeho pozdější odpovědnosti vǔči věřícím, před nimiž bude stát jako kazatel.

V souvislosti s množinou studentů, které můžeme označit jako Husovy žáky, stojíme před jedním z problémů husovského bádání. Počet jmen v této kategorii není stabilizován a kolísá rámcově v rozpětí mezi $20-40$ osobami. Musíme se ptát, proč se tak děje. Na vině je především pojmová neujasněnost kategorie „žáka některého z mistrư‘, ale také neúplnost záznamů $\mathrm{v}$ děkanské knize. Nemáme $\mathrm{k}$ dispozici údaje typu: kdo poslouchal čí přednášky, s kým trávil cvičné disputace atp. Zcela výjimečně dochované záznamy přednášek nebo vysvědčení o splněných povinnostech docházky na přednášky ${ }^{17}$ nejsou pro to dostatečně směrodatné, nebot' suma povinných předmětů byla dána a čtení byla mistrům regentům přidělována, aby nikdo z rádných učitelů nepřišel zkrátka.

Děkanská kniha pak přináší pro tuto otázku dvojí údaje. Pravidelně byly voleny zkušební komise, jejichž obsazení se ř́́dilo paritním zastoupením univerzitních národů. Pokud byl tedy adept zkoušen některým profesorem, neplyne $\mathrm{z}$ toho automaticky jejich bližší vztah učitele a žáka, ale také jej nelze vyloučit. Hus byl zvolen do zkušební komise pouze třikrát (dvakrát u bakalářŭ a jednou u magistrů), navíc dvakrát předsedal komisi jako děkan (u bakalářù i magistrů). ${ }^{18}$ Relativně malé vytížení zkušební činností je zarážející, soustřed’uje se do let 1398-1408, ačkoli další učitelské záležitosti konal Hus až do roku 1412. $\mathrm{K}$ pochopení této situace bychom se mohli přiblížit jedině provedením rozboru obdobné situace u dalších mistrů a hledáním analogií nebo protikladů. Fakt, že zkušební aktivity

13 K motivaci či determinaci pro tuto dráhu (neměl jiné zajištění - církevní beneficium; nedosáhl zatím dostatečného věku na místo faráře ani kazatele) viz F. ŠMAHEL, Jan Hus, s. 22-23; tamtéž s. 42 o tom, že si pedagogickou činností ,„prrivydělával na živobytí“; dále s. 43 o povrchnosti jeho prríprav na výuku, ale na druhé straně velmi pečlivá a časově náročná př́prava na kvodlibet 1411.

$14 \mathrm{~K}$ pojmu a výčtu osob František KAVKA, Mistři-regenti na artistické fakultě pražské university $v$ letech 1367-1420. Statistická studie, in: Z českých dějin. Sborník prací in memoriam prof. dr. V. Husy, Praha 1966, s. 77-96.

15 Matěj z Knína a Matěj z Újezda, viz LD I, s. 339 a 343; LD-faksim., s. 184 a 185 (folio 92v a 93r).

16 Tato možnost, přijímaná jen částí autorů, vychází z nejisté atribuce rekomendace Studuit agere quod iustum est (č. 1 u Schmidtové) Husovi (v LD I, s. 331, zápis o zkoušení, Hus v komisi nebyl, doklad o promoci a Husově promluvě chybí). K osobě Jana Černého Josef TŘíšKA, Životopisný slovník předhusitské pražské univerzity 1348-1419, Praha 1981, s. 299. Husovo autorství stanovil Bohumil RyBa, Nový Hus. Nepoznané universitni promluvy Mistra Jana, Listy filologické 71, 1947, s. 1-12, 57-86, 269-277; 72, 1948, s. 25-32, zde roč. 71, S. 57-65; jako Husova je řeč vedena i v soupise jeho literární činnosti: F. M. BARToš - P. SPUnAR, Soupis pramenů, s. 90-91, č. 32. Atribuci zpochybnila A. Schmidtová (ed.), Iohannes Hus, ... Positiones, s. 223; nejnověji vydáno v českém překladu bez pochybností in: J. NechutovÁ - J. Fuksová (edd.), Mistr Jan Hus v polemice a za katedrou, s. 58-64.

17 Srov. např. František ŠMAHEL, Statuta antiqua, kalendária a soupisy přednášek pražské artistické fakulty, in: týž, Alma mater Pragensis. Studie k počátkům Univerzity Karlovy, Praha 2016, s. 303-325 (s odkazem na starší německá vydání).

18 LD I, s. 336, 368-369, 377, 396; LD-faksim., s. 182, 199, 206, 219 (folia 91v, 100r, 103v, 110r). Zde nacházíme také níže v textu jmenované zkoušené studenty. 
nezakládaly bližší vazby ke studentům, potvrzuje i to, že pouze po jednom zkoušení je Hus doložen také jako promotor někoho ze zkoušených, nelze ale vyloučit další nezachycené př́pady. ${ }^{19} \mathrm{Z}$ řečeného dále plyne, že musíme jako náhodu vyhodnotit skutečnost, že se mezi zkoušenými za přítomnosti Husa objevili jeho budoucí přátelé, stoupenci i odpůrci - jen pro ilustraci např́klad Jan Kbel (1401), Albert Varrentrappe (1402), Prokop z Plzně (1403 a 1408) nebo Jan z Jesenice (1408).

Druhým typem informací děkanské knihy jsou záznamy o promocích (determinacích a incepcích) ${ }^{20}$ Ty mají zřejmě individuálnější charakter - jak se obecně předpokládá, zachycují vazbu studenta a konkrétního mistra. Z nich tedy snad můžeme vycházet při úvahách o Husových žácích ve smyslu studentů, kteří měli k Husovi blíže (aniž většinou dokážeme říci něco konkrétnějšího). U těch, kteří si jej vybrali za promotora, ale těžko poznáme, zda se tak stalo pro shodu myšlenkovou, blízkost krajanskou, nebo jen proto, že byl oblíbený. Jako promotor vystupuje Hus v letech 1399-1412, tedy po dobu 14 let. Zpočátku uvádí při ceremoniálu jen kandidáty bakalářského titulu, teprve v roce 1402 promuje (jako děkan) prvé tři magistry. ${ }^{21}$ Dále se pak obojí promoce stř́idají. Bakalářủ, jejichž promotorem byl Hus, zaznamenává děkanská kniha 12, magistrů 11. Pouze jedna osoba vystupuje v obou kategoriích, jedná se tedy celkově o 22 absolventů. Čistě zprůměrováno by to bylo 1,5 studenta ročně. Reálně promoval Hus v prvých letech (1399-1402) každoročně dva studenty i více, po nástupu v Betlémě však musely být jeho aktivity na univerzitě zjevně utlumeny, další promoce přicházejí nárazově (1404 tři, 1409 dvě, 1410 šest, 1412 jedna, a to jako poslední na konci února). Ukončení této činnosti jistě souvisí s počátkem jeho procesu a následným odchodem z Prahy na venkov. ${ }^{22}$

Uvedená čísla a fakta ukazují, že Hus patřil k učitelům oblíbeným, ale nikoli těm, kteří odpromovali největší počty studentů. Na tom nic nezmění ani mírné navýšení počtu odpromovaných po započtení těch, kteří jsou doloženi jinak než zápisem v Liber decanorum (LD), jak ještě uslyšíme. Podle čísel uváděných F. Šmahelem byla nejaktivnějšími pedagogy starší generace německých mistrů šedesátých až sedmdesátých let (40 až 80 žáků na osobu), střední generace Husových učitelů vykazuje 40 až 60 žáků na osobu; nejmladší generace Husova se pak pohybuje podobně jako Hus na nižších číslech 20 až 30 promovaných. ${ }^{23}$

19 Při incepci 3 magistrů v únoru 1402 figuruje Hus jako děkan, nejprve předsedá zkušební komisi a pak 3 adepty promuje, viz LD I, s. 368-369; LD-faksim., s. 199 (folio 100r). Podle A. Schmidtové (ed.), Iohannes Hus, ... Positiones, s. 225, zkoušející prý častěji také zkoušené promoval, proto na základě zkoušek přisuzuje některé promoční texty Husovi a konkrétním studentům. Ověření této praxe u Husa ale argumentaci nepotvrzuje. V letech 1403 a 1408 nejsou ovšem promoce zaznamenány, takže případů mohlo být více, než je doloženo.

20 Průběh promocí obojího typu líčí A. Schmidtová (ed.), Iohannes Hus, ... Positiones, v doslovu na s. $220-221$. Srov. František KaVKA, Organisace studia na pražské artistické fakultě v době predhusitské, Acta Universitatis Carolinae - Historia Universitatis Carolinae Pragensis (dále AUC-HUCP) 8/1, 1967, s. 7-39.

21 Nejranější magisterskou promocí by měla být podle Ryby ta, při níž zazněla řeč Proice omnia ista, datovaná jím kol. r. 1400, u níž není znám kandidát a také autorství Husovo je odvozeno pouze ze stylistické podoby. Viz Ryba, Nový Hus, s. 79-86; A. Schmidtová (ed.), Iohannes Hus, ... Positiones, s. 223.

22 F. Šmahel, in: Svatoš Michal (ed.), Dějiny Univerzity Karlovy, I, 1347/48-1622, Praha 1995 (dále Dějiny UK), I, s. 123; odlišná, vyšší čísla uvádí TÝž, Jan Hus, s. 42, 116, podle F. M. BARToš, Hus jako student (1958). Započteni byli v tom př́ípadě i ti, kdo jsou doloženi jen laudací, a další osoby, které přišly s Husem do přátelského kontaktu. A. Schmidtová (ed.), Iohannes Hus, ... Positiones, s. 228, vyjmenovává incepce mistrů pod Husem, je jich 11, nikoli 12 jak uvádí. Tradičně, na základě Bartošovy studie, představil Husa-pedagoga Olivier MARIN, Geneze pražského reformního hnuti 1360-1419, Praha 2017, s. 28.

23 Základním vodítkem přehledu může být F. Šmahel, Dějiny UK, I, s. 122-123; TÝž, Dějiny fakulty svobodných umění 1348-1419, in: týž, Alma mater Pragensis, s. 231-302, zde s. 260-262 (pro starší generace uvádí počty promovaných, u mladších mistrů, kolegů Jana Husa, už se soustředí bohužel spíše na jejich literární 
Dodejme k této statistice ještě tři poznámky:

1) sestavení záznamů o zkouškách a promocích obsažených v LD jasně ukazuje, že manuálník neobsahuje veškeré údaje. U všech zkoušených nemáme zprávu o jejich promoci; u magistrů pak v některých letech chybí záznam o konání zkoušek; „statistiku“ (a tady již musíme užít uvozovek) proto musíme brát jako rámcovou, orientační možnost zjištění kvantity pedagogické práce mistra regenta - což platí samozřejmě i pro Husa. Neúplnost úředních záznamů dokazují i dochované promoční proslovy, z nichž některé směřují k osobám, jejichž promoce není zaznamenána ( $\mathrm{k}$ tomu se ještě vrátím).

2) Za předpokladu, že volba promotora je výrazem užšího vztahu žáka a učitele, mohli bychom očekávat, že se některá jména, případně jejich většina, objeví v rádiu daného mistra dvakrát, že své žáky bude promovat na bakaláře i mistra. Jak už bylo vzpomenuto, u Husa se tak podle děkanské knihy stalo pouze jednou, a sice u Mikuláše z Jistebnice (1401, 1404). ${ }^{24}$ Druhým studentem, kterého představoval Hus zřejmě při obou promocích, byl šlechtic Zdislav ze Zvířetic, jehož determinace je doložena jen Husovou promoční řečí. ${ }^{25}$

3) Z doložených dvaceti dvou Husem promovaných osob lze za Jihočechy označit asi polovinu - jejich místa původu se ale nesoustřed'ují do oblasti pravděpodobného Husova rodiště. Vedle nich promoval Hus dva Pražany a také cizince - jednoho Chorvata (Martin z Křiževců), jednoho studenta z Polska a dva z Uher; ${ }^{26}$ u magisterských promocí se objevuje i student z Chebu, který absolvoval bakalaureát u německého mistra, podobně jako Řehoř z Budína. Z Polska pocházel Bernard z Přemyšlu, který získal bakalářský titul v Erfurtu a při magisterské promoci v Praze jej uvedl Hus. ${ }^{27}$

Dalším zdrojem informací o promotorské činnosti Jana Husa jsou rekomendace pronášené mistrem na závěr slavnosti, jejichž byl podle rukopisného svědectví autorem, nebo které jsou mu připisovány. Obsahují určitou charakteristiku absolventa, a dovolují tak nahlédnout blíže do vztahu Husa k jeho žákům. Problémem ovšem je, že neobsahují všechny potřebné údaje, aby bylo možné spojit je vždy s konkrétní osobou promovaného, a tím je i datovat. $\mathrm{V}$ řadě případů je i autorská atribuce Husovi jen více či méně pravděpodobnou dedukcí znalců Husova díla. Pozornost jim byla již věnována opakovaně, jsou k dispozici v edicích i překladech, přesto je s nimi spojena řada otazníků.

S Husem bylo dosud spojováno patnáct promočních rekomendací, z nichž Anežka Vidmanová jednu rozhodně vyloučila a u dalších šesti není Husovo autorství nepochybné. Jen asi šest řečí lze jednoznačně spojit se studenty (asi osmi), které Hus podle děkanské knihy promoval. Z promočních řečí vystupuje oproti LD dalších asi osm jmen bakalářů,

pozůstalost). Uvedené skutečnosti mohou souviset s vývojem poměru počtu mistrů a studenti̊, kdy počet mistrů stále stoupal, zatímco frekvence posluchačů rostla pomaleji, resp. od 90. let klesala, jak upozornil Jiří STOČES, Pražské univerzitni národy do roku 1409, Praha 2010, s. 90-94.

24 LD I, s. 361, 363, 377, 378; J. TŘíšKA, Životopisný slovník, s. 392 (Nicolaus de Gistebnicz).

25 Řeč vydala A. Schmidtová (ed.), Iohannes Hus, ... Positiones, s. 71-75; identifikace a atribuce promoční řeči při magisterské promoci je nejistá, viz tamtéž, s. 94-96 a 228. Ke Zdislavovi LD I, s. 384, 407, 409; J. TŘišKA, Životopisný slovník, s. 542; F. M. BARToš, Hus jako student, s. 20-23, ke spojení Husa a Zdislava; TÝŽ, Husưv žák, rektor Karlovy university Zdislav ze Zvíretic, Kostnické jiskry 41/34, 11. 10. 1956, s. 3.

26 Z Košic (Georgius de Cassovia) a Budína (Gregorius de Buda); z Polska přišel Bernard z Přemyšlu, viz dále. J. TŘíšKA, Životopisný slovnik, s. 133 (eviduje pouze Řehoře, Jiřího pominul), k Martinovi z Křiževců tamtéž, s. 353; srov. záznamy LD I, s. 405 (Jiří), 334, 369, 379 (Řehoř), 369 a 370 (Martin).

27 Václav z Chebu: LD I, s. 336 (ve zkušební komisi i Hus), 337(determinace 30. 12. 1398 u Františka Creisewicze z Brzegu), 369 (incepce pod Husem); k Bernardovi LD I, s. 343, 378, 379, pro oba J. TŘíšKA, Životopisný slovník, s. 46, 522. Řehoř z Budína determinoval u Ondřeje Marienwerdera koncem r. 1398 (LD I, s. 334). 
jež možná Hus promoval, která jsou ovšem pouhým dohadem. Celkový počet jím promovaných žáků tak lze stř́źlivě určit jako interval 25-30 osob. Proslovy se týkají především determinantů, jichž můžeme blíže poznat pomocí těchto půvabných textů asi třináct. Pro incepce jsou známy řeči čtyři, ale jen u tř́ lze stanovit jméno promovaného. ${ }^{28}$

Vedle Husem promovaných absolventů se objevuje celá řada jmen dalších studentů, kteří jsou označováni jako jeho žáci. Ukotvení tohoto zařazení není většinou pevné a plyne povýtce z jejich věkového rozdílu a blízkosti k mistrovým snahám, nebo z jiných okolností. Hus jim např́klad pomáhal v různých životních situacích. Zde můžeme připomenout především Jeronýma Pražského, za něhož se Hus přimluvil roku 1399 za prominutí biennia ${ }^{29}$ jinou učitelskou vazbu uvést nelze.

Ani pozice Petra z Mladoňovic jako žáka není jednoznačná. Jeho promotor není znám, je s ním ale spojována hypoteticky jedna z promočních řečí Husových. Pokud by bylo toto určení správné, objevil by se před námi Petr jako studentík s rezavým vousem, sangvinik nepř́liš bystrý: „Pilně se učili plných osm let" (totiž s druhým promovaným bakalářem Janem, snad Př́bramem?). Podle Husa ovšem ,při jakékoli práci se dá nedostatek nadání nahradit pilli“". Petr se pro tato slova neurazil a soudě podle jeho zaujatého vypsání Husova procesu a smrti svého mistra miloval a ctil. ${ }^{30}$

Studentů blízkých Husovi bylo jistě více, ale z dostupných pramenů jich vystupuje málo. Velmi osobním dokumentem je Husův testament, v němž pamatuje na Martina z Volyně, kterého bychom jinak s Husem nespojovali, podobně jako jeho fámuly Jana Faráře a Jiříka, kteří zůstávají zahaleni v historickém šeru. ${ }^{31}$ Další jména se objevují na protestu proti spálení knih v roce 1410.32 Jako Husovi studenti bývají uváděni i ti, kteří měli být ubytováni při Betlémské kapli, respektive posléze v kolejích Litevské a Nazaretské. Když ale uvážíme nejasné počátky a relativně pozdní konstituování těchto institucí (1411-1412), bude se muset naše představa o situaci v těchto zařízeních poněkud uskrovnit: Jan z Mülheimu sice myslel na jednoho chudého studenta teologie při kapli, další ubytovací možnosti však řešil až kramář Kř́žz v uvedených letech. Datování některých dokumentů v kapli nebo Křížově domě ještě neznamená, že uvedení svědci z řad studentů tam bydleli. Okruh Husových žáků tedy jistě rozšiřují i další jeho sympatizanti z řad studentů, nejednoznačná je však

28 Jan Sedlák, Husovy promluvy promoční, Studie a texty I, 1914, s. 119-128; B. RyBa, Nový Hus, 1. c.; A. SchmidtovÁ, Husovy universitní promluvy, in: Táž (ed.), Iohannes Hus, ... Positiones, s. 217-244; z ní vycházely J. Nechutová - J. FuKsová (edd.), Mistr Jan Hus v polemice a za katedrou, zde na s. 117 odkazy na další jednotlivá vydání rekomendací a jejich starší překlady. K výběru nutno dodat, že editorky nezavrhly všechny texty odmítané A. Vidmanovou. Relativní neshoda mých součtů vzniká tím, že někdy se rekomendace týká dvou osob zároveň.

29 LD I, s. 338; LD-faksim., s. 183 (folio 92r). K Jeronýmovi František ŠMAHEL - Gabriel SILAGI (edd.), Magistri Hieronymi de Praga Quaestiones, polemica, epistulae, Turnhout 2010; F. Šmahel, Život a dílo Jeronýma Pražského. Zpráva o výzkumu, Praha 2010.

30 Pouhým dohadem je údajná př́́mluva Husa, aby Mladoňovic získal místo v koleji Královny Hedviky, viz např. Michal Svatoš, Hussens Freunde, in: Ferdinand Seibt (Hg.), Jan Hus zwischen Zeiten, Völkern, Konfessionen. Vorträge des internationalen Symposions in Bayreuth vom 22. bis 26. September 1993, München 1997, s. 67-72, zde s. 71. Citát v textu vzat z překladu J. Nechutová - J. Fuksová (edd.), Mistr Jan Hus v polemice a za katedrou, s. 83.

31 Martin z Volyně a fámulové Jiř́ik a Plebán (Farář) vystupují v Husových dopisech, zvl. v testamentu, viz Václav Novotný (ed.), M. Jana Husi korespondence a dokumenty, Praha 1920, s. 204-206, č. 86, a dále podle rejstř́iku. Srov. k tomu F. M. BARToš, Husũv žák Plebán, Jihočeský sborník historický (dále jen JSH) 13, 1940, s. $129-130$.

32 Viz P. Soukup, Jan Hus. Život a smrt kazatele, s. 87; Martin NodL, Dekret kutnohorský, Praha 2010, s. 312. 
otázka jejich zajištění př́mo $\mathrm{v}$ areálu kaple - někteří mohli nanejvýš nalézt útočiště v domě kazatelově. Mezi prvními obyvateli Litevské koleje nacházíme jen dvě jména vystupující mezi alespoň pravděpodobně doloženými Husovými žáky (Mikuláš ze Stojčína a Petr z Mladoňovic). Záhy po definitivním ustavení obou kolejí navíc Hus opouští nuceně Prahu (podzim 1412). ${ }^{33}$

Pro poznání na jedné straně Husa jako člověka, který nepostrádal smysl pro humor a hlavně své kolegy a studenty dobře znal, a na straně druhé pro poznání povah a slabůstek jeho žáků jsou nejužitečnější již zmiňované promoční rekomendace a dále tzv. arengy, uvádějící jednotlivé mluvčí př̌i Husově kvodlibetu z roku 1411. Úloha kvodlibetáře, kterou Hus na sebe vzal dobrovolně, aby univerzita po secesi německých akademiků nevešla do posměchu, byla náročnou akcí, v níž vrcholí učitelská a teologicko-filozofická práce Husa na univerzitě. ${ }^{34}$

Můžeme tedy uzavřít první úvahu tím, že přesná a jednoznačná statistika Husovy pedagogické činnosti není možná. Brání tomu jak nedostatečné pramenné doklady, tak jejich povaha, která odráží jiný charakter a postup studia, než jaký známe dnes.

S Husovou pedagogickou činností souvisí také velký objem spisů, které se dochovaly, nebo jen o nich víme, že existovaly. Bez ohledu na přesný počet děl a řadu otazníkủ kolem atribucí, datací a deperdit tvoří spisy spojené s univerzitou vedle kazatelských postil druhou největší část Husovy literární pozůstalosti, jejiž obsah je celkově zmapován opakovaně aktualizovanými soupisy díla. ${ }^{35} \mathrm{Je}$ ovšem těžké přesně vydělit, co patř́i $\mathrm{k}$ univerzitě a co nikoli, až na skutečně typické univerzitní žánry, jako jsou povinné komentáře stanovených děl, kvestie, rekomendace a projevy ve funkci rektora. ${ }^{36}$ Do určité míry lze identifikovat také kázání při univerzitních mších, kdy bakalář nebo magistr teologie vystupoval na

33 F. M. Bartoš umist’uje do Betléma a s ním svázaných kolejí všechny Husem promované studenty a všechny obyvatele Litevské koleje považuje za Husovy žáky, což nemá pevnou oporu v pramenech, viz F. M. BARTOš, Hus jako student, s. 16-17. Takovou interpretaci odmítl také F. ŠmaHEL, Jan Hus, s. 246, pozn. 243. K mojí úvaze srov. údaje in: Michal Svatoš, Litevská kolej pražské univerzity (1397-1622), in: Jan Petr - Luboš Reháček (edd.), Praha - Vilnius. Sborník prací k 400. výročí založení univerzity ve Vilniusu, Praha 1981, s. 19-31, zde s. 23 (výčet prvních 12 obyvatel Litevské koleje); F. M. BARToš, První století Betléma, in: Betlémská kaple. O jejích dějinách a zachovaných zbytcích, Praha 1922, s. 9-21, zvl. s. 11; Mlada HolÁ, Nazaretská kolej pražské univerzity v pozdním středověku, in: Eva Doležalová - Petr Sommer (edd.), Středověký kaleidoskop pro muže s hůlkou: věnováno Františku Šmahelovi k životnímu jubileu, Praha 2016, s. 511-521.

34 Husův př́pravný materiál vydal Bohumil RyBA † (ed.), Magistri Iohannis Hus Quodlibet, Turnhout 2006 (Opera omnia MIH XX; Corpus Christianorum, Continuatio Mediaevalis 211;), pův. vydání v roce 1948; ke kvodlibetu obecně Jiří KEJŘ, Kvodlibetni disputace na pražské universitě, Praha 1971; František ŠMAHEL, Die Verschriftlichung der Quodlibet-Disputationen an der Prager Artistenfakultät bis 1420, in: Schriften im Umkreis mitteleuropäischer Universitäten um 1400: Lateinische und volkssprachige Texte aus Prag, Wien und Heidelberg: Unterschiede, Gemeinsamkeiten, Wechselbeziehungen, Leiden - Boston 2004, s. 63-91; průběh kvodlibetní disputace popsal také E. STEIN (ed.), M. Jan Hus jako universitní rektor a profesor, s. 8-9, ukázky z Husových proslovů na kvodlibetu v českém překladu na s. 15-17, 103-120. Srov. i pozn. 7.

35 Václav FlajšHans, Literární činnost M. Jana Husi, Praha 1900; F. M. BARToš, Literární činnost M. Jana Husi, Praha 1948; F. M. BARToš - Pavel Spunar, Soupis pramenů k literární činnosti M. Jana Husa a M. Jeronýma Pražského, Praha 1965; Anežka Vidmanová, Základní vydání spisů M. Jana Husa, in: Jan Hus na přelomu tisíciletí (HT-Supplementum 1), Tábor 2001, s. 267-277.

36 Vedle dvou nástupních projevů sem patří i slavnostní kázání při zádušní mši za Karla IV., konané v roce 1409 nejspíše 3. 12. (LČ-Hus, s. 83-84, č. 23, datuje na 29. 11.; uvedená datace na první prosincovou středu podle A. Schmidtová (ed.), Iohannes Hus, ... Positiones, s. 236, kde je řeč i vydána na s. 119-130; překlad E. STEIN (ed.), M. Jan Hus jako universitní rektor a profesor, s. 74-89); o rektorských projevech F. M. BARTOš, M. J. Hus jako rektor; projevy vydal TÝž, Dvě rektorské řeči Husovy (oboje v pozn. 2). 
kazatelnu před shromážděné kolegy a studenty. U Husa bylo bezpečně rozpoznáno šest takových vystoupení z let 1404-1410 a tři nejistá. ${ }^{37}$ Tematika ostatních traktátů, polemik a výkladů vychází z myšlenkových bojů formujících se na univerzitě a prostupuje dále do ostatních působišt', především do betlémských kázání. Zatímco přednášky držené na artistické fakultě známe jen jménem, ${ }^{38} \mathrm{z}$ teologické fakulty se dochovaly čtyři důležité výklady. ${ }^{39}$ Vedle kvodlibetní př́ručky je k dispozici dalších deset kvestií, které jsou jen přibližně datované a není možné je přiřadit ke konkrétním událostem (kvodlibetům nebo cvičným disputacím) ${ }^{40}$

Třetí okruh otázek - to je role reprezentanta fakulty a univerzity. Hus ji vzal na sebe dvakrát. Opět není třeba detailněji připomínat jeho děkanát v roce 1401/1402 a rektorát na podzim 1409. Nesmíme však pohlížet na tyto funkce dnešníma očima - trvaly jen jeden semestr a nezanechávaly zpravidla hluboké stopy v univerzitním organismu. Jako děkan zapisoval Hus běžnou agendu udělování univerzitních gradů; jen z drobné poznámky na př́ídeští děkanské knihy se dozvídáme, že také nakládal s fakultními penězi - půjčku 70 kop koleji Krále Václava museli totiž vymáhat jeho nástupci a provedli o tom záznam. ${ }^{41}$

Co se týče Husova rektorství, připomeňme v rámci bilancování, že už odezněly pochyby o věrohodnosti zprávy o jeho volbě rektorem, a to díky nálezu jeho rektorských řečí. ${ }^{42} \mathrm{Na}$ druhé straně není pochyby ani o tom, že rektorem byl pouze jednou, v zimním semestru 1409/1410.43 Funkce rektora nebyla tak exkluzivní záležitostí jako v moderní době, přesto musíme podtrhnout, že někdy okolnosti volby určité osoby mohly být demonstrací postojů: $\mathrm{k}$ těm patř́ i Husova volba rektorem, vykonaná nedlouho po secesi zahraničních akademiků (17. 10. 1409), a to již podle nového volebního rádu. ${ }^{44}$ Jako rektor byl Hus účasten úpravy

37 Výklad o fenoménu univerzitní mše a rozbor vystoupení Husových podala A. SchmidTová (ed.), Iohannes Hus, ... Positiones, s. 229-244; patří sem i obě Husovy řeči na pamět' Karla IV., o mladší viz pozn. 36, starší pronesl nejspíše 1. 12. 1404 (tamtéž, s. 234). K univerzitnímu kazatelství dále P. Soukup, Jan Hus. Život a smrt kazatele, s. 36; TÝž, Reformní kazatelství a Jakoubek ze Střibra, Praha 2011, s. 157-187; srov. Jindřich MAREK, Jakoubek ze Střibra a počátky utrakvistického kazatelství v českých zemích, Praha 2011; Zdeněk UHLír, Středovéké kazatelství v českých zemích: nástin problematiky, Almanach historyczny 7, 2005, s. 57-94.

38 Přehled informací o Husových přednáškách na artistické fakultě a výčet textů doložených v dobových katalozích a dnes nedochovaných uvádí F. ŠMAHEL, Jan Hus, s. 42-43; srov. dále P. SouKuP, Jan Hus. Život a smrt kazatele, s. 77-78. Pokus (později odmítnutý) najít zápisy z Husových přednášek např.: F. M. BARToš, Po stopách nezvěstné Husovy rétoriky, JSH 9, 1936, s. 21-28.

39 LČ-Hus, s. 66-70, č. 1-5.

40 Jiří KeJর̌, Husovy kvestie, in: Husitství - Reformace - Renesance, I, Praha 1994, s. 239-316 (přetisk in: TÝŽ, Z počátků české reformace, Praha 2006, s. 195-211); edice TÝž, Magistri Iohannis Hus Questiones, Turnhout 2004 (Opera omnia MIH XIXa; Corpus Christianorum, Continuatio mediaevalis 205). Dvě kvestie jsou spojovány s konkrétními studenty, pro něž měly být připraveny: pro Jana z Vlhlav (promoce 10. 12. 1409) a Mikuláše z Pavlíkova (promoce 3. 4. 1410), viz LČ Hus (1948), č. 36 a 40.

41 LD I, s. 132; LD-faksim., s. 6 (folio 1v) - zapsal Hening Boltenhagen.

42 Husovo rektorství zpochybnil František RYšÁNEK, Husovy rektoráty universitní, Listy filologické 57, 1930, s. 89-120; jeho pochyby opakovaně odmítl Bartoš, který snesl i doklady, v tomto př́padě přesvědčivé, pro upřesnění data volby a jeho činnosti, srov. např. F. M. BARToš, Datum Husovy volby rektorem pražské university, JSH 4, 1931, s. 83-84. K promluvám viz pozn. 36.

43 Mylný první rektorát z r. 1402/1403 se tradoval již od F. Palackého, přijímal jej např. V. V. Tomek, K. Krofta, V. Flajšhans, V. Novotný i J. Sedlák, odmítl jej Ryšánek (pozn. 42) stejně jako Bartoš (pozn. 2 a jiné). Další autoři se k němu už nevracejí, naposledy problém shrnul F. Šmahel, Jan Hus, s. 262, otázka D.

44 K mandátu Václava IV., vydanému v Kutné Hoře, M. NodL, Dekret kutnohorský, Praha 2010. Srov. dále F. M. BaRToš, Př́spěvky k dějinám Karlovy university v době Husově a husitské, I-V, Sborník historický 4, 1956, s. 33-70 (k dekretu s. 33-40); Jiří KeJর̌, Sporné otázky v bádáni o Dekretu kutnohorském, AUC-HUCP 3/1, 1962, s. 83-122; F. M. BARToš, M. J. Hus jako rektor; TÝž, Dvě rektorské řeči Husovy (oboje v pozn. 2). 
celouniverzitních statut; založil proto novou knihu statut, v níž se na čelním místě ocitl záznam o Dekretu kutnohorském; příslušná folia byla ale zničena, takže nemůžeme poznat podrobnosti. 45

V rámci univerzitní samosprávy vystupuje Hus velmi zřídka. V roce 1399 je zachycen dvakrát jako svědek při propuštění studenta z bursy, což byla zřejmě formalita, která neměla širší souvislosti. ${ }^{46} \mathrm{O}$ rok později byl zvolen za český národ do komise přidělující knihy mistrům k lekcím a v roce 1401 do komise pro dispenze. ${ }^{47}$ Tím je jeho (doložené) zapojení do správy univerzity vyčerpáno. Vedle toho ale stojí od roku 1402 jeho již připomenuté spravování kaple Betlémské, jejíž propojení s univerzitou, včetně dvou na ni vázaných studentských kolejí v sousedství (o nichž již byla také zmínka), je dobře známé, ${ }^{48}$ a plné nasazení v této funkci je naprosto dostačujícím vysvětlením absence ostatních úloh.

Svědectví děkanské knihy můžeme ještě doplnit o informace z listinného fondu. ${ }^{49}$ Z ranějšího období se vztahují k Husovi dvě listiny z roku 1403, z nichž jedna obsahuje rozhodčí výrok ve sporu betlémského kazatele (Jana Husa) a faráře sv. Filipa a Jakuba, jímž byl Husův spolužák Mikuláš Zeiselmeister. ${ }^{50}$ Druhá listina dosvědčuje darování kaple Božího těla českému univerzitnímu národu, které přijímal Hus. ${ }^{51}$ Oba dokumenty dokládají poměrně rutinní záležitosti, k nimž můžeme přiřadit i mladší listinu z roku 1411, v níž Hus vystupuje v pozici prvního betlémského kazatele jako svědek stvrzení statut koleje Královny Hedviky. ${ }^{52}$ Podobně je doložena i Husova spoluúčast na transakci, při níž byl českému národu zapsán dům na Ovocném trhu (10. 1. 1404), později (1413) získaný Litevskou kolejí. ${ }^{53}$ Teprve skupina listin z let 1411-1415 představuje vrchol zápasu o Husa na domácí půdě a postoj univerzity v něm. K tomu se dostaneme v závěru.

45 O knize statut Gustav Friedrich, Dekret kutnohorský. Poměr jeho rukopisných textů, Český časopis historický (dále ČČH) 15, 1909, s. I-XII, zde s. IV; F. M. BARTOš, Zapadlá památka Husovy činnosti jako rektora Karlovy university, JSH 9, 1936, s. 38-40; TÝž, M. J. Hus jako rektor, s. 26; F. ŠMAHEL, Nejstarši statuta pražské univerzity. Prolegomena k jejich edici, in: týž, Alma mater Pragensis. Studie k počátkům Univerzity Karlovy, Praha 2016, s. 43-61.

46 LD I, s. 344, 348; LD-faksim., s. 185, 187 (fol. 93r, 94r). Prvý - Matyáš z Újezda - byl Husem krátce před tím i promován, druhý - Jan z Borotína - studoval až do r. 1410, ale s Husem není v zápisech jinak spojován.

47 LD I, s. 357, 364; LD-faksim., s. 192, 196 (fol. 96v, 98v).

48 F. M. Bartoš, První století Betléma, s. 12-14; kritické shrnutí F. Šmahel, Husitská revoluce II, Praha 1993, s. 209-213; srov. i B. ZiLYnská, Pražská univerzita - patron církevních beneficií?, AUC-HUCP 47/1-2, 2007, s. 75-87; Mlada Holá, Studentské koleje pražské univerzity a staroměstský měšt’an Kř̌ž, Mediaevalia Historica Bohemica 18/2, 2015, s. 95-132.

49 Karel Kučera - Miroslav Truc, Archiv University Karlovy. Průvodce po archivních fondech, Praha 1961, s. 81-99: Listiny. K osudům fondu a jeho (ne)úplnosti Michal Svatoš, Rozsah a původní podoba listinného fondu pražské univerzity, AUC-HUCP 25/2, 1985, s. 15-33. Listiny jsou dostupné také v digitalizované podobě, viz: <http://digitool.is.cuni.cz/R/NU842GBTFG7DV1JS1R43BM5JMI1TSPSPFVR3JXXYTEV3 NE3RLL -01491 ? func $=$ collections\&collection $\mathrm{id}=2133 \&$ pds handle $=$ GUEST $>$ (ověřeno 7. 12. 2017).

50 AUK, listiny, sign. I/54, 1. 4. 1403, MUP II/1, č. LII, s. 399-406.

51 AUK, listiny, sign. I/55, 28. 6. 1403, MUP II/1, č. LIII, s. 406-410. Jiné jeho angažmá v souvislosti s touto kaplí známo není. Ke kapli a jejímu spojení s univerzitou Miroslav PolívKA, K šírení husitství v Praze. Bratrstvo a kaple Božiho Téla na Novém Městě pražském v předhusitské době, Folia historica Bohemica 5, 1983, s. 95-118; srov. nověji Jan Hrdina, Kaple Božiho Těla na Novém Městě pražském v době předhusitské - dvě drobné sondy, Staletá Praha 29/2, 2013, s. 21-38, resp. TÝž, Relikvie, odpustky, poutni odznaky. Čtyři kapitoly z náboženského života lucemburské Prahy, Praha 2017, s. 11-54.

52 AUK, sign. I/61, z 29. 4. 1411, vč. Husovy pečeti; otisk Josef TEIGE, Základy starého místopisu pražského, II, Praha 1912, s. 809-810, č. 46.

53 F. M. BARtoš, Zapomenutý dokument Husovy činnosti v universitní Natio Bohemica, JSH 12, 1939, s. 102-103; M. Svatoš, Litevská kolej, s. 23. Další podrobnosti M. HolÁ, Studentské koleje pražské univerzity, s. 112-113. 
Univerzita nebyla jen školou, na níž získal Hus vzdělání, a místem, kde nalezl zaměstnání. Husův osud byl s univerzitou provázán více, než si dovedeme v první chvíli uvědomit. Bylo to i místo setkávání, seznamování, společenského uplatnění a angažovanosti - utvářely se tu postoje, které našly výraz v následujících letech a desetiletích husitského vzplanutí. Husovo spojení s univerzitou tak mělo i širší společenský rozměr, který zasahoval jednak do oblasti ideové, věroučné, a jednak vytvářel jeho společenské vazby a vztahy.

Akademické prostředí bylo garantem správného výkladu teologických otázek. Univerzita proto stavěla mantinely pro myšlení dobových učenců. Zodpovědnost v tomto směru si uvědomil Husův přítel Štěpán z Pálče,${ }^{54}$ když jako profesor teologické fakulty couvl z dosavadní společné cesty, kdežto Hus se nechal unášet dál svým přesvědčením a na akademické konvence nepřistoupil: akademické prostředí mu to nezapomnělo.

Do konfliktní pozice se Hus dostal poprvé roku 1403 při jednání o Viklefově učení, další př́ípady pak přicházely stále častěji a jsou dobře známy - proces Husova žáka Matěje z Knína, žaloby pražských farářů, žaloba na české stoupence Viklefa atd. ${ }^{55}$

Filozoficko-teologické otázky posléze překročily meze akademického dialogu a staly se politikem a předmětem inkvizičního zkoumání. Do této veřejné, politické dimenze náležejí záležitosti kolem Dekretu kutnohorského, žaloby na arcibiskupa podané studenty za Husovy podpory, ${ }^{56}$ boj o Betlém (1410) i odpustková aféra (1412), při níž se viklefská strana na univerzitě silně angažovala velkou disputací podobně jako při obraně Viklefova učení. V interním prostředí univerzity měly tyto politické události charakter zápasu Husa s teologickou fakultou. ${ }^{57}$ I to patř́ do škály vztahů Jana Husa s univerzitou.

Společenské vazby, které si zde Hus vytvořil, byly četnější než ty, které mohl navázat v rámci církve. Nejednou byla probírána plejáda jeho učitelů, kolegů a žáků, přátel i protivníků. ${ }^{58} \mathrm{O}$ žácích jsme už mluvili výše. Co se týká Husových učitelů, platí zde stejný princip,

54 M. Jan Hus a M. Štěpán Páleč. Sborník z kolokvia usporádaného referátem kultury OÚ Kladno 25. 5. 2000 v klášteře bosých karmelitánů ve Slaném, Kladno 2000; J. TŘišKa, Životopisný slovník, s. 491-492; Jaroslav KADLEC, Katoličtí exulanti čeští doby husitské, Praha 1990, s. 12-14.

55 K. Krofta, Hus a pražská universita, s. 14-15; V. Novotný, M. J. Hus, I/1, passim; K. Malý, Mistr Jan Hus a Univerzita Karlova, s. 398-401; M. NodL, Dekret kutnohorský, s. 156-180; F. ŠMAHEL, Jan Hus, s. 54, 63-66; P. Soukup, Jan Hus. Život a smrt kazatele, s. 45-59; ke Knínovi J. TřišKA, Životopisný slovnik, s. 364.

56 F. M. Bartoš, M. J. Hus jako rektor, s. 19-21; P. Soukup, Jan Hus. Život a smrt kazatele, s. 87 (v době Husova rektorátu podala skupina studentů žalobu na arcibiskupa za jeho snahu likvidovat opisy Viklefových děl - Hus není mezi žalobci, ale vzhledem ke své funkci je vnímán jako postava v pozadí této akce). Konflikt Husa s arcibiskupem odrážejí také dvě listiny, viz dále pozn. 65. K politické dimenzi Husova působení viz Petr ČoRNEJ, Homo politicus, in: A. Paner - M. Hintz (edd.), Jan Hus, s. 84-105; Dušan Coufal, Hus mezi univerzitou, kazatelnou a veřejností, in: Petr Čornej - Václav Ledvinka - Jan Hrdina (edd.), Praha Husova a husitská 1415-2015, s. 65-74.

57 Události popisuje veškerá životopisná literatura, srov. pozn. 55, k Dekretu pozn. 44. Dále F. M. BARTOš, Hus a jeho učitelé a kolegové na bohoslovecké fakultě Karlovy university, JSH 13, 1940, 41-47. Nejvýraznějším dokladem jsou materiály spjaté s mimořádnou synodou v únoru 1413, vydané in: František PALACKÝ (ed.), Documenta Mag. Joannis Hus vitam, doctrinam, causam in Constantiensi concilio actam ... illustrantia (dále jen Documenta), Pragae 1869, s. 472-505, č. 51.

58 Anežka VidmanovÁ, Stoupenci a protivníci mistra Jana Husi, Husitský Tábor 4, 1981, s. 49-56 (sleduje spíše ohlas Husova díla v pracích jeho souvěkovců); Jaroslav KADLEC, Husovi odpůrci, in: Jan Hus na přelomu tisíciletí (HT-Supplementum 1), Tábor 2001, s. 325-342; Zdeňka HledíkovÁ, Hussens Gegner und Feinde, in: F. Seibt (Hg.), Jan Hus zwischen Zeiten, Völkern, Konfessionen, s. 91-102; M. Svatoš, Hussens Freunde, tamtéž, s. 67-72; česká verze in: Jan Blahoslav Lášek (ed.), Jan Hus mezi epochami, národy a konfesemi. Sborník př́spěvků z mezinárodního sympozia, konaného 22.-26. záŕí 1993 v Bayreuthu, SRN, Praha 1995, s. 63-67. Univerzitní milieu, do něhož Hus přišel, nejnověji celkově zhodnotil Martin Dekarli, ,Antiqui“, , moderni“", „, universaliste“, „,nominales “: Jan Hus a pražská univerzitní tradice mezi roky 1366 až 1409, Theologická 
jako u jeho žáků: za učitele můžeme totiž považovat všechny mistry, jejichž přednášky Hus pravděpodobně poslouchal nebo mohl navštěvovat. Při hledání osob Husovi bližších je pak nutno držet se konkrétně podložených kontaktů. Na prvním místě stojí Jan z Mýta, který o Husovi zanechal svědectví ve své promoční promluvě při determinaci: „homo contemplativus adaptat alas suo intellectui. Utique noster est hic determinans alas habens, nam avis nomen, quia Auca nuncupatur. Per alas sic se in superiora erigit per contemplacionem." 59 V druhé fázi studia byl určitě osobností s největším vlivem na Husa Stanislav ze Znojma, který jej examinoval u mistrovské zkoušky, ale chybí záznam o incepci, takže nevíme, zda byl také jeho promotorem. Ke Stanislavovi se Hus hlásil a dojemně i zklamaně hodnotil jeho obrat $v$ př́stupu $\mathrm{k}$ Viklefově nauce. ${ }^{60}$

Kolegové - to je široká kategorie, která by nás přivedla jak mezi Husovy přátele, tak do řad jeho protivníků různého ražení - byli konkurenty v církevní kariéře, ideovými oponenty, soupeřili o místa a směřování univerzity, což vyústilo do událostí kolem Dekretu kutnohorského. $\mathrm{O}$ tom všem bylo hodně napsáno, proto tyto skutečnosti jen připomínám. $\mathrm{Na}$ konec je na místě též zopakovat, že všechny pramínky se stékají v Kostnici, kde najdeme přátele, protivníky i velmi aktivní nepřátele... ${ }^{61}$

Pestrá škála osudů, postojů a povah osob obklopujících Husa ukazuje, že vztah mistra Jana a univerzity musíme vidět jak z úhlu institucionálního, tak individuálního. Hus sám akcentuje vztah svůj i ostatních kolegů $\mathrm{k}$ jejich Alma mater $\mathrm{v}$ jedné z promluv, kdy hovořil k Martinu z Křiževců na téma Bud' dobrým synem: ,Vaše matka, artistická fakulta, z jejíchž prsou jste bohatě sál mléko vědeckého poznání, vám ted' jako svému synu [...] touži dát dar" - míněn je bakalářský titul. ${ }^{62}$

Univerzita prožívala s Husem jeho proces a reagovala na něj - souhlasně i odmítavě, souběžně s tím, jak se prohluboval rozkol uvnitř reformní univerzitní strany. Hus musel být pro univerzitu problémem - jedni jej obdivovali a šli za ním, druzí vnímali více to, že Hus strhává univerzitu do podezření z šíření kacířských nauk, stává se pro ni zátěží, která ji táhne ke dnu.

Jak se tedy univerzita stavěla $\mathrm{k}$ Husovu procesu? Univerzita jako celek, to byli ve chvíli odchodu Husa na koncil především mistři českého národa artistické fakulty, nebot' jak př́śslušníci zahraničních národů, tak teologové, a do jisté míry i právníci byli vypuzeni,

revue 87/1, 2016, s. 62-101. Dále srov. Petr HLAvÁČEK, Scholares Pragenses: Husovi němečtí spolužáci na pražské univerzitě, Theologická revue 87/1, 2016, s. 102-113 (věnovaný především Konradovi Konhoferovi); ke slezské skupině Blanka ZiLYnSKÁ, Johann Hoffmann: Prager Student, antihussitischer Repräsentant und Bischof von Meissen, in: táž (ed.), Universitäten, Landesherren und Landeskirchen: Das Kuttenberger Dekret von 1409 im Kontext der Epoche von der Gründung der Karlsuniversität 1348 bis zum Augsburger Religionsfrieden 1555, AUC-HUCP 49/2, 2009, s. 81-98.

59 Bohumil RyBA, Promoční promluvy mistrů artistické fakulty Mikuláše z Litomyšle a Jana z Mýta na Universitě Karlově z let 1386 a 1393, Praha 1948, s. 48; heslo Johannes de Muta viz J. TříšKa, Životopisný slovník, s. 281-282, dodatky TÝž, Přispěvky k bibliografím středověkých pražských osobností, Miscellanea Oddělení rukopisů a starých tiskủ Národní knihovny v Praze 9, 1992, s. 5-42.

60 Ke Stanislavovi heslo in: J. TŘišKa, Životopisný slovník, s. 488; J. KadLec, Katoličtí exulanti, s. 5-12.

61 Viz pozn. 58. O účastnících koncilu nově: P. Elbel, Die Delegation der Prager Kirchenprovinz; Pavel Soukup, Die böhmischen Konzilsteilnehmer zwischen Häresiebekämpfung und Kirchenreform. Die Konstanzer Predikten von Mauritius Rvačka, Stephan von Páleč und Matthäus von Königsaal, in: Gabriela Signori - Birgit Studt (Hgg.), Das Konstanzer Konzil als europäisches Ereignis. Begegnungen, Medien und Rituale, Ostfildern 2014, s.173-217.

62 J. Nechutová - J. Funsová (edd.), Mistr Jan Hus v polemice a za katedrou, s. 79. 
nebo jejich činnost utlumena. Tady stejně jako u ostatních otázek platí, že pro zhodnocení činnosti Husa, postojů jeho kolegů a role univerzity vůbec, by byl zapotřebí zejména prosopografický výzkum ${ }^{63}$ (když pominu odkrývání textového bohatství literární pozůstalosti akademiků). ${ }^{64}$ Přesné vysledování osobních osudů a vazeb, zjištění počtu profesorů činných v daný okamžik atd. pomůže vyhnout se povrchním soudům, které přebírají stará klišé.

K postižení role univerzity v závěru Husova života pomáhá skupina vzácně dochovaných listin, které dokládají zájem instituce o problémy jejího mistra, projevený pořizováním věrohodných kopií nebo prŕmo angažováním se v jeho kauze. Ukazují nejprve snahu vyřešit na domácí půdě konflikt univerzity s arcibiskupem, jehož předmětem byl Hus, a svěřují jej králi a jeho radě (1411). ${ }^{65} \mathrm{Na}$ univerzitní půdě se dochoval také notářsky ověřený obsah listiny, jíž Hus vydává počet ze své víry papeži Janu XXIII. ${ }^{66}$ V roce 1414 pak vzniká skupina ověřených kopií důležitých dokladů, které měly pomoci Husovi jako důkazní materiál v Kostnici - je mezi nimi Dekret kutnohorský pod univerzitní pečetí spolu s usnesením univerzitní obce k němu (září 1409), ${ }^{67}$ protest Husa a studentů proti spálení knih (1410) ${ }^{68}$ a list českých pánů dosvědčující, že arcibiskup neshledal na Janu Husovi žádné kacířství a neviní ho z něj. ${ }^{69}$ Notářské instrumenty se prripravovaly z iniciativy českých mistrů - Husových stoupenců a vypovídají o snaze univerzity přispět k př́znivému zakončení Husova procesu. Sem patří i spis Jana z Jesenice shrnující dosavadní průběh procesu. ${ }^{70}$

Do Kostnice vyslala univerzita vlastní posly (mezi nimi mistr Jan Kardinál z Rejštejna, Husem promovaný na magistra). ${ }^{71} \mathrm{~V}$ průběhu procesu na koncilu došly do Kostnice výzvy českomoravské šlechty na obranu Jana Husa. Akce z května 1415 byla složitě organizována a vyvolala ohlas i v univerzitních kruzích. ${ }^{72}$ Hus psal průběžně mnoha přátelům včetně univerzitánů, př́mo na univerzitu se ale obrátil jen jednou v čase, kdy se blížil konec jeho

63 Jeho náznak viz např. P. SoukuP, Jan Hus. Život a smrt kazatele, s. 84-92. Univerzitní prosopografii (nikoli ve spojení s Husem) pěstuje Jiř́ STOČEs, Kariéry př́islušniků saského národa pražské právnické univerzity imatrikulovaných v letech 1386-1417, AUC-HUCP 52/2, 2012, s. 17-28.

64 Srov. např. pozn. 12 a 35. Celkově představil univerzitní prostředí doby Husovy O. MARIN, Geneze pražského reformniho hnuti, passim.

65 AUK, listiny, sign. I/62 a I/63. Jedná se o dohodu univerzity s arcibiskupem Zbyňkem podat vzájemnou při k nálezu králi z 3. 7.1411 a rozhodčí výrok královských rádců ve sporu Husa s arcibiskupem z 6. 7. 1411, ed. Documenta, s. 434-440, č. 40 a 41.

66 AUK, listiny, sign. I/64, 1. 9. 1411, ed. Documenta, s. 18-20, č. 9.

67 AUK, listiny, sign. I/68, 18. 9. 1414, ed. Documenta, s. 347-348, č. 10 (pouze text samotného Dekretu).

68 AUK, listiny, sign. I/69, 18. 9. 1414. Výčet osob s apelací spojených viz P. Soukup, Jan Hus. Život a smrt kazatele, s. 87. Apelace ve formě notářského instrumentu z r. 1410 (nikoli její ověření r. 1414) vydána in Documenta, s. 387-397, č. 25.

69 AUK, listiny, sign. I/70, 7. 10. 1414, ed. Documenta, s. 531-532, č. 63.

70 Ordo procedendi, o něm Jiří KeJর̌, Husitský právník M. Jan z Jesenice, Praha 1965, zvl. s. 165-166, č. 16.

71 F. M. BARToš, Zástupci Karlovy university na kostnickém koncilu, in: Sborník prací G. Friedrichovi k 60. narozeninám, Praha 1931, s. 1-8. Dále srov. pozn. 61.

72 Univerzitní archiv obsahuje originál listu posílaného z Čech českým dvořanům Zikmunda do Kostnice (AUK, listiny, sign. I/71, 12. 5. 1415, ed. Documenta, s. 554-555, č. 75, čes. a lat.; Václav NovotnÝ, Hus v Kostnici a česká šlechta. Poznámky a dokumenty, Praha 1915, s. 54-56, č. 6, čes.). Nedořešen zůstává důvod tohoto archivního uložení. Angažovanost univerzity ve věci Husa naznačují i fingované listy, jimiž se měla pražská univerzita obracet na obec města Kostnice, resp. přimlouvat se za Husa a Jeronýma u kardinálů - editor datuje do ledna, resp. května až června r. 1415, viz V. Novotný, Hus v Kostnici, s. 56-58, č. 7 a 8. Srov. k tomu Božena KopičKovÁ - Anežka Vidmanová, Listy na Husovu obranu z let 1410 - 1412. Konec jedné legendy?, Praha 1999, s. 167-180; Aleš PoŘízKa, Listy na obranu Husovu ze 12. záři až 2. října 1410. Konec druhé legendy?, ČC 
procesu a jeho dopisy nabývaly charakteru duchovního kšaftu a napomenutí. ${ }^{73}$ Po vykonání exekuce na Husovi se univerzita připojila k protestu nobility Čech a Moravy a také sama vydala o Husovi velmi př́iznivé, až oslavné svědectví (dobrozdání z 11. září 1415).74

Tady však již začíná nová kapitola ve vztahu Husa a univerzity - ta legendární, která se proměňuje v souznění s politickou a náboženskou situací. Hus se stává devizou, ikonou, jejíž literární odkaz stojí poněkud v pozadí. Po peripetí́ch pobělohorské rekatolizace se pak vrací i do univerzitního prostředí jako národní hrdina, slavný mistr Karlova učení, rektor a mučedník. Tuto druhou kapitolu už sledovat nebudeme. ${ }^{75}$

\section{BLANKA ZILYNSKÁ}

\section{Magister Jan Hus und die Prager Universität: Gedanken über mögliche Erkenntnisse ihrer Beziehungen zueinander und über Hussens pädagogische Tätigkeiten}

\section{ZUSAMMENFASSUNG}

Hussens Berufs- und Privatleben war mit der Prager Universität verbunden. Neben einer Zusammenfassung der verschiedenen Aspekte ihrer gegenseitigen Beziehung konzentriert sich dieser Beitrag vor allem auf die Frage der Schüler von Hus, ihrer Zahl und der Möglichkeit ihrer Identifizierung. Erinnert wird auch an Hussens Funktionen im Rahmen der universitären Selbstverwaltung mit Überlegungen zu ihrer Wichtigkeit. Außer dem Amtsbuch des Dekans wird auch der Urkundenbestand des Universitätsarchivs herangezogen, um das Engagement der Universität im Falle von Hus aufzuzeigen.

Deutsche Übersetzung Wolf B. Oerter

Blanka Zilynská

Ústav dějin a archiv UK

blanka.zilynska@ruk.cuni.cz

73 Documenta, s. 142-143, č. 87 (Johannes Hus Universitati studii Pragensis, 27. 6. 1415). Mj. nabádá ke svornosti mistrů českého národa, který se už tehdy rozestupoval na stoupence a odpůrce Viklefových nauk.

74 Václav Novotný (ed.), Fontes rerum Bohemicarum VIII, Praha 1932, s. 228-230 (Testimonium Universitatis Pragensis de M. Johanne Hus et Hieronymo de Praga), komentář k tomu tamtéž, s. LXIX-LXX.

$75 \mathrm{~K}$ tomu nejnověji Adam Honký, Dějiny ve vlastní režii. Př́běh dějin Karlovy univerzity v proměnách 20. století, AUC-HUCP 55/2, 2015, s. 17-80, zde zvl. s. 23-27. 